\title{
Вплив ауксинів на вкорінення живців Begonia L.
}

\section{Оксана Сіжук, Валентина Андресва}

Східноєвропейський національний університет імені Лесі Українки, Луцьк, Україна

Адреса для листування: andreevav@i.ua

Отримано: 23.09.18; прийнято до друку: 06.11.18; опубліковано: 26.12 .18

Резюме. Бегонії - поширені кімнатні рослини, які невибагливі до умов вирощування та доволі декоративні. Методику вегетативного розмноження бегонії листковими й стебловими живцями детально описано в підручниках із квітникарства, практикумах і наукових статтях. Мета статті - установити ефективність використання фітогормонів для вкорінення листкових та стеблових живців окремих видів роду Begonia L. Відповідно до мети ставили такі завдання: установити, чи $є$ ауксини стимуляторами ризогенезу стеблових і листкових живців Begonia L. та дослідити тривалість й інтенсивність укорінення живців бегонії при використанні різних доз ауксинів.

Живцювання досліджуваних рослин проводили в березні. Ми використали стеблові живці бегонії коралової (Begonia coralina Carr.), стеблові й листкові живці бегонії люцерна (B. coralina «Lucerna»), бегонії Шмідта (B. Schmidtiana Regel), бегонії металевої (B. Metalica G. Smith), листкові живці бегонії тигрової (В. «Tiger Paws» bowerae var. nigromarga) і манжетної (B. Manicata Prongn.). Живці взято зі здорової частини материнської рослини. Спочатку їх помістили на 12 годин у розчини фітогормонів: ІОК - 25 мг/л, ІМК - 25 мг/л, IОК + ІМК 25+25 мг/л, після цього як середовище вкорінення використовували дистильовану воду. Еталонним розчином була вода без додавання ауксинів. Після появи додаткових корінців для обліку вкорінених живців застосовано методику Ботанічного саду НУБіП України, що передбачає проведення кількісної та якісної оцінки.

Отримані результати свідчать, що для вегетативного розмноження бегонії люцерна, бегонії металевої й бегонії Шмідта ми рекомендуємо використовувати стеблові живці, які гарно реагують на екзогенне внесення IMК (25мг/л). Живці, які перебували у воді без дії фітогормонів, загинули в бегонії коралової й люцерна, не вкоренились у бегонії тигрової, дуже слабко вкоренились у бегонії манжетної, задовільно у бегонії металевої та Шмідта. Очевидно, живці досліджуваних варіантів потребують екзогенного впливу ауксинів. Найкращим стимулятором ризогенезу для досліджуваних видів бегоній є розчин IMК (25 мг/л), при якому спостерігали загалом задовільне вкорінення. На екзогенне внесення IОК (25 мг/л) живці бегонії реагують специфічно. Приживлюваність усіх досліджуваних видів бегоній становила 100 \%. Усі варіанти утворили рослини, які перебувають на стадії бутонізації або рясного цвітіння.

Ключові слова: вегетативне розмноження, ауксини, фітогормони, живці, ризогенез.

\section{Auxine's Influence on Rooting Cuttings of Begonia L.}

\section{Oksana Sizhuk, Valentyna Andreyeva}

Lesia Ukrainka Eastern European National University, Lutsk, Ukraine

Correspondence: andreevav@i.ua

\begin{abstract}
Begonias are widespread indoor plants that are unpretentious to growing conditions and quite decorative. The method of vegetative reproduction of Begonia by leaf and stem-cuttings is described in detail in the textbooks on floriculture, workbooks and scientific articles. The purpose of the article was to set efficiency for rooting phytohormones leaf and stem cuttings of some species of the genus Begonia L. The article tasks were: determine whether auxin stimulants rhizogenesis stem and leaf cuttings of Begonia L. and study duration and intensity of rooting cuttings of begonias using various doses of auxines.

Trimming of the studied plants was carried out in March. We have used stem cuttings of Begonia coralina, stem and leaves cuttings of B. luserna, B. schmidtiana, B. metalica, leaves cuttings B. tiger and B. manicata. Cuttings were taken from a healthy part of the mother plant. At first they were placed for 12 hours in solutions of
\end{abstract}


phytohormones: IAA - $25 \mathrm{mg} / \mathrm{l}$, IBA - $25 \mathrm{mg} / \mathrm{l}$, IAa + IBA $25+25 \mathrm{mg} / \mathrm{l}$, then distilled water was used as a rooting substance.

The standard solution was water without adding auxins. After the emergence of additional roots to account for rooted cuttings, we use the methodology of the Botanical Garden of NUBiP of Ukraine, which provides for quantitative and qualitative estimation.

The obtained results indicate that for vegetative reproduction of B. lucerna, B. metalica and B. schmidtiana we recommend using stems, which are responded well to the exogenous introduction of IBA $(25 \mathrm{mg} / \mathrm{l})$. Cuttings, which were in water without the action of phytohormones, died in B. coralina and $B$. lucerna, not rooted in $B$. tiger, very weakly rooted in B. manicata, and satisfactorily in the B. metalica and B. schmidtiana. Obviously, the cuttings of the studied variants require the exogenous influence of auxins. The best stimulator of rhizogenesis for the studied types of begonias is a solution of IBA $(25 \mathrm{mg} / \mathrm{l})$, in which a generally satisfactory rooting is observed. On an exogenous application of IAA $(25 \mathrm{mg} / \mathrm{l})$, begonias cuttings react specifically. The survival percent of all studied species of begonias was $100 \%$. All variants have formed plants that are in the stage of budding or abundant flowering.

Key words: vegetative reproduction, auxins, phytohormones, cuttings, rhizogenesis.

\section{Вступ}

В інтер'єрах різноманітного функціонального призначення все більше уваги приділяють фітодизайну, оскільки озеленення закритих середовищ наближає природу до людини, покращує мікроклімат, приносить естетичну й душевну насолоду, а також виконує фітоергономічні функції.

Бегонії - поширені кімнатні рослини, оскільки вони невибагливі до умов вирощування та доволі декоративні. Особлива ï цінність полягає в наявності вишуканих листків та квітів. Велика різноманітність сортів бегоній спроможна задовольнити найвибагливіші смаки людей. На сьогодні бегонії використовують в озелененні приміщень різних функціональних призначень [1-3].

Методику вегетативного розмноження бегонії листковими й стебловими живцями детально описано в підручниках із квітникарства та інших літературних джерелах $[4 ; 5 ; 6 ; 7]$. Проте практично не висвітлено можливість застосування синтетичних стимуляторів укорінення, тривалість їх дії та концентрацію. Можлива причина цього - той факт, що листкові й стеблові живці бегонії легко вкорінюються у водному середовищі без додавання фітогормонів чи інших речовин. Ми вирішили перевірити, чи варто використовувати ауксини для вкорінення стеблових та листкових живців бегонії, у яких ризогенез відбувається успішно та без додаткового стимулювання.

За даними С. Н. Приходько й Н. Я. Попової, із допомогою гетероауксину (індолілоцтової кислоти - ІОК) i його аналогів нафтилоцтової (НОК), індолілмасляної кислоти (IMК) та ін. - можна прискорити вкорінювання живців різних видів рослин [8; 9]. Ф. Я. Полікарповою встановлено, що випередження в розвитку коренів під впливом
ІМК становило місяць [10]. У рослин, які отримували екзогенну IOK, майже удвічі збільшується інтенсивність фотосинтезу [11]. Попередніми дослідженнями встановлено, що для листкових живців найкращим стимулятором ризогенезу в бегонії королівської $\epsilon$ IMK (100 мг/л), у бегонії кореневищностеблової - ІМК та ІОК (50 мг/л), у тигрової - IMK (50 мг/л) та IOК (25 мг/л), у бегонії Бауера IОК (100 мг/л), у Клеопатра - ІОК (50мг/л) та IMК (25, 50 мг/л) [12]. Бульбові бегонії (Begonia $\times$ Tuberhybrida) сортів «Camelia» i «Picotee» важко розмножуються листковими живцями навіть у разі використання стимуляторів ризогенезу [13].

Мета статті - установити ефективність застосування фітогормонів для вкорінення листкових та стеблових живців окремих видів роду Begonia L. Відповідно до мети ставили такі завдання: установити, чи $€$ ауксини стимуляторами ризогенезу стеблових i листкових живців Begonia L. та дослідити тривалість й інтенсивність укорінення живців бегонії за використання різних доз ауксинів.

\section{Матеріали й методи досліджень}

Живцювання досліджуваних рослин проводили в березні. Використано стеблові живці бегонії коралової (Begonia coralina Carr.), стеблові й листкові живці бегоній люцерна (В. coralina «Lucerna»), Шмідта (B. Schmidtiana Regel), металевої (B. Metalica, G. Smith), листкові живці бегонії тигрової (B. «Tiger Paws» bowerae var. nigromarga) та манжетної (B. Manicata Prongn.). Живці взято зі здорової частини материнської рослини. Спочатку їх помістили на 12 годин у розчини фітогормонів: ІОК - 25 мг/л, ІМК - 25 мг/л, IОК + IMК 25+25 мг/л, після цього як середовище вкорінення використовували 


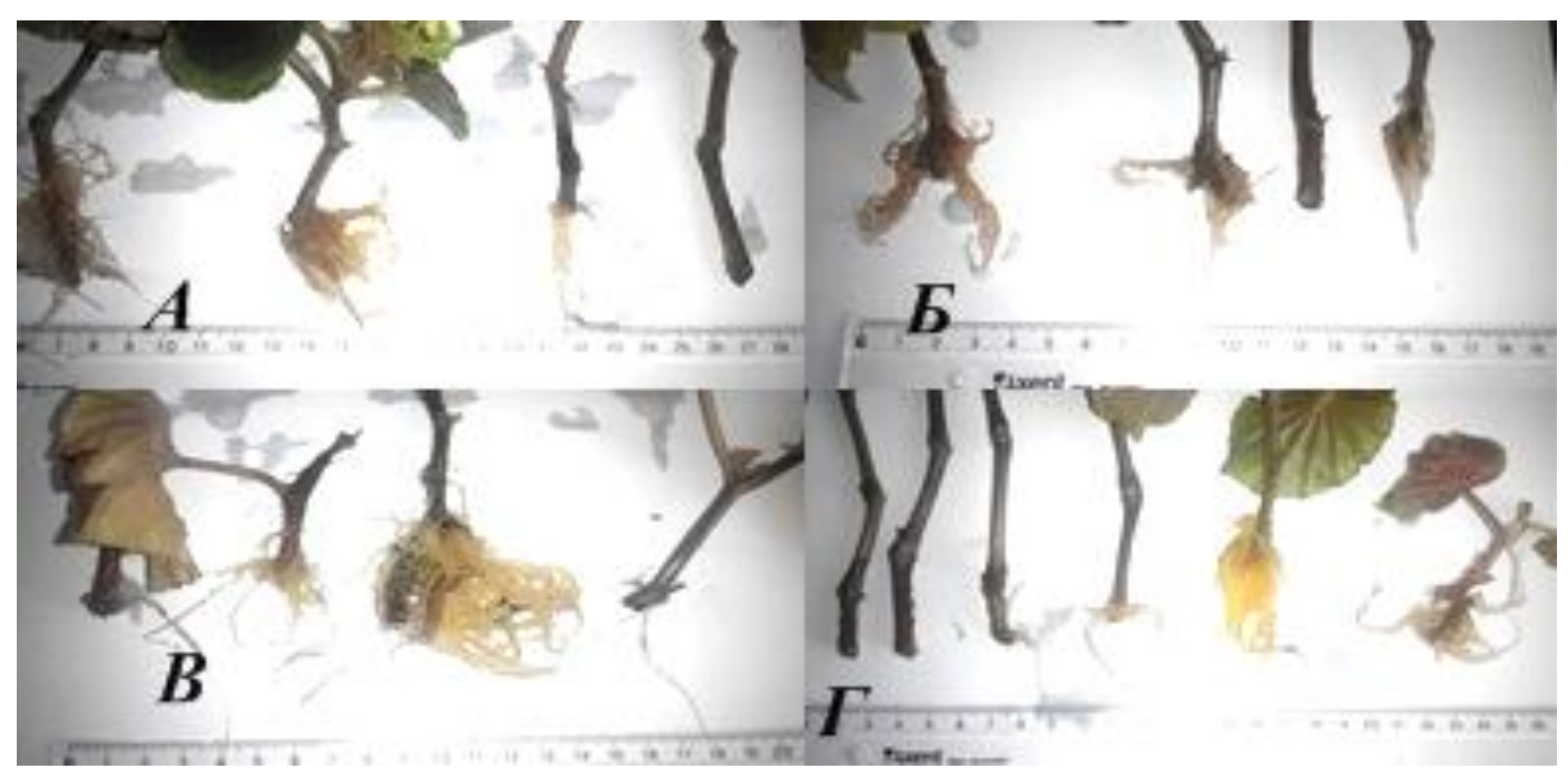

Рис. 1. Стеблові живці бегонї Шмідта, які витримувались

y A - IOK (25 мг/л); Б - IMК (25 мг/л); В - IOK + IMК (25 + 25 мг/л); Г - воді

дистильовану воду. Еталонним розчином була вода без додавання ауксинів.

Після появи додаткових корінців (на 56-й день) для обліку вкорінених живців використано методику Ботанічного саду НУБіП України, що передбачає проведення кількісної та якісної оцінок [14].

\section{Результати й обговорення}

Характеризуючи вкорінення бегонії коралової, можемо сказати, що найкраще вкоренилися стеблові живці, які утримувались у розчині IMК. У розчині IOК укорінення $\epsilon$ слабким, але все ж таки воно наявне (табл. 1). Живці, які піддалися дії суміші ауксинів, i контрольний варіант загинули.

Спостерігаючи за вкоріненням бегонії люцерна, зауважимо, що найкращим стимулятором укорінення для живців слугував розчин IMК (25 мг/л). Інтегрований показник укорінення становить $100 \%$. Трохи слабше вкорінення можемо спостерігати в розчині IOK (25 мг/л). Інтегрований показник ризогенезу $50 \%$ Ж Жиці в решті варіантів досліду загинули.

Таблиия 1

Інтегровані показники вкорінення стеблових живців

\begin{tabular}{|c|c|c|c|c|c|}
\hline Назва & $\begin{array}{l}\text { Варіант } \\
\text { досліду }\end{array}$ & $\begin{array}{c}\text { Концентрація, } \\
\text { м2/л }\end{array}$ & $\begin{array}{c}\text { Кількість } \\
\text { укорінених } \\
\text { живців, \% } \\
\end{array}$ & $\begin{array}{c}\text { Інтегрований } \\
\text { показник } \\
\text { укорінення, \% }\end{array}$ & $\begin{array}{l}\text { Успішність } \\
\text { укорінення }\end{array}$ \\
\hline \multirow{4}{*}{$\begin{array}{c}\text { Бегонія } \\
\text { коралова }\end{array}$} & IOK & 25 & 50 & 33,3 & Слабке \\
\hline & IMK & 25 & 50 & 41,7 & Задовільне \\
\hline & IOK +IMK & $25+25$ & 0 & 0 & Живці загинули \\
\hline & вода & - & 0 & 0 & Живці загинули \\
\hline \multirow{4}{*}{$\begin{array}{c}\text { Бегонія } \\
\text { люцерна }\end{array}$} & IOK & 25 & 100 & 50 & Задовільне \\
\hline & IMK & 25 & 100 & 100 & Дуже добре \\
\hline & IOK +IMK & $25+25$ & 0 & 0 & Живці загинули \\
\hline & вода & - & 0 & 0 & Живці загинули \\
\hline \multirow{4}{*}{$\begin{array}{c}\text { Бегонія } \\
\text { металева }\end{array}$} & IOK & 25 & 80 & 40 & Слабке \\
\hline & IMK & 25 & 100 & 53 & Задовільне \\
\hline & IOK +IMK & $25+25$ & 40 & 20 & Дуже слабке \\
\hline & вода & - & 60 & 33 & Задовільне \\
\hline \multirow{4}{*}{$\begin{array}{l}\text { Бегонія } \\
\text { Шмідта }\end{array}$} & IOK & 25 & 80 & 40 & Слабке \\
\hline & IMK & 25 & 80 & 48 & Задовільне \\
\hline & $\mathrm{IOK}+\mathrm{IMK}$ & $25+25$ & 80 & 53 & Задовільне \\
\hline & вода & - & 100 & 53 & Задовільне \\
\hline
\end{tabular}




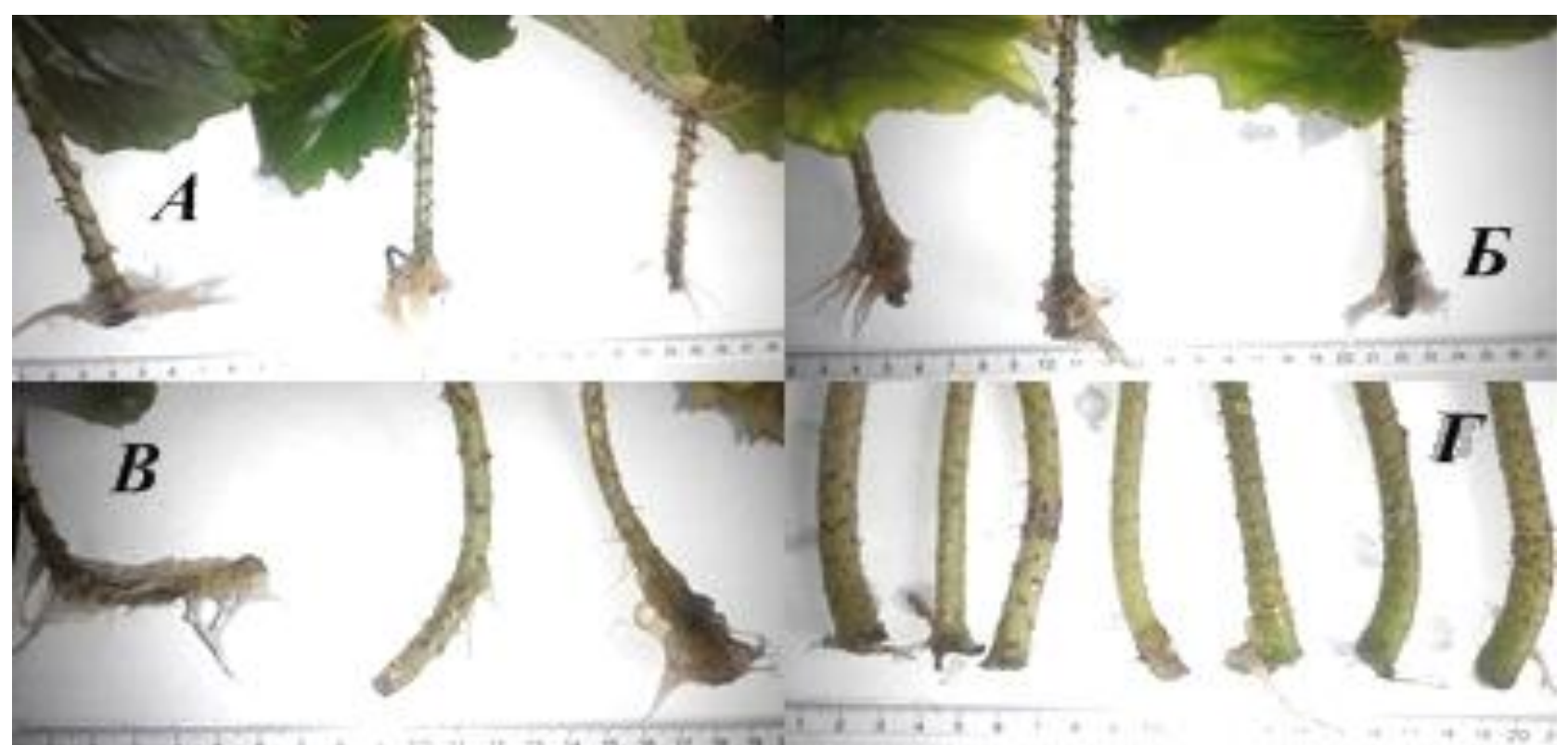

Рис. 2. Укорінені листкові живиі бегонії манжетної, які витримувались у А - IMК (25 мг/л); Б - ІОК (25 мг/л); В - IОК + ІМК (25 + 25 мг/л); Г - воді

Задовільним укоріненням можна схарактеризувати стеблові живці бегонії металевої, які витримувалися в ІМК (25 мг/л) та воді. Дуже слабке вкорінення можна простежити в розчині суміші IOК+IMК $(25+25$ мг/л).

У бегонії Шмідта листкові та стеблові живці по-різному вкорінились у різних стимуляторах. Найкращими 3-поміж них для стебло- вих живців бегонії Шмідта $є$ розчини ІМК (25 мг/л), ІОК+ІМК (25+25 мг/л) і вода, у яких спостерігали задовільне вкорінення. У розчині IOК простежено слабкий ризогенез (рис. 1).

Усі листкові живці бегоній люцерна та металевої в ході досліду загинули. Аналізуючи результати вкорінення листків бегонії манжетної можна стверджувати, що найкраще

Таблиия 2

\section{Інтегровані показники укорінення листкових живців}

\begin{tabular}{|c|c|c|c|c|c|}
\hline Назва & $\begin{array}{l}\text { Варіант } \\
\text { досліду }\end{array}$ & $\begin{array}{c}\text { Концентрація, } \\
\text { мz/л }\end{array}$ & $\begin{array}{c}\text { Кількість } \\
\text { укорінених } \\
\text { живців, \% }\end{array}$ & $\begin{array}{c}\text { Інтегрований } \\
\text { показник } \\
\text { укорінення, \% }\end{array}$ & $\begin{array}{l}\text { Успішність } \\
\text { укорінення }\end{array}$ \\
\hline \multirow{4}{*}{$\begin{array}{c}\text { Бегонія } \\
\text { люцерна }\end{array}$} & IOK & 25 & 0 & 0 & Живці загинули \\
\hline & IMK & 25 & 0 & 0 & Живці загинули \\
\hline & IOK +IMK & $25+25$ & 0 & 0 & Живці загинули \\
\hline & вода & - & 0 & 0 & Живці загинули \\
\hline \multirow{4}{*}{$\begin{array}{c}\text { Бегонія } \\
\text { манжетна }\end{array}$} & IOK & 25 & 60 & 70 & Добре \\
\hline & IMK & 25 & 60 & 54 & Задовільне \\
\hline & IOK +IMK & $25+25$ & 60 & 46 & Задовільне \\
\hline & вода & - & 78 & 18 & Дуже слабке \\
\hline \multirow{4}{*}{$\begin{array}{c}\text { Бегонія } \\
\text { металева }\end{array}$} & IOK & 25 & 0 & 0 & Живці загинули \\
\hline & IMK & 25 & 0 & 0 & Живці загинули \\
\hline & IOK +IMK & $25+25$ & 0 & 0 & Живці загинули \\
\hline & вода & - & 0 & 0 & Живці загинули \\
\hline \multirow{4}{*}{$\begin{array}{l}\text { Бегонія } \\
\text { тигрова }\end{array}$} & IOK & 25 & 60 & 10 & Дуже слабке \\
\hline & IMK & 25 & 60 & 40 & Задовільне \\
\hline & IOK +IMK & $25+25$ & 33 & 10 & Дуже слабке \\
\hline & вода & - & 0 & 0 & Не вкоренились \\
\hline \multirow{4}{*}{$\begin{array}{l}\text { Бегонія } \\
\text { Шмідта }\end{array}$} & IOK & 25 & 67 & 67 & Добре \\
\hline & IMK & 25 & 0 & 0 & Живці загинули \\
\hline & IOK +IMK & $25+25$ & 33 & 11 & Дуже слабке \\
\hline & вода & - & 67 & 67 & Добре \\
\hline
\end{tabular}



вкорінилися живці, які витримувались у розчині IОК (25 мг/л). Їх інтегрований показник укорінення становить 70 \%. Дещо слабші властивості спостерігали в розчинах IMK (25 мг/л) і суміші IMК+IOK $(25+25$ мг/л). Інтегрований показник укорінення в цих розчинах становить 54 і $46 \%$ відповідно (табл. 2, рис. 2). Бегонія тигрова не проявила високих властивостей щодо вкорінення, проте найкращим стимулятором для неї виявився розчин IMK (25 мг/л), при дії якого спостерігали задовільні показники. Дуже слабке вкорінення бегонії присутнє в розчині IOK (25 мг/л) і в суміші IOK+IMK (25+25 мг/л). У воді живці не вкоренились.

Найкращим стимулятором ризогенезу листкових живців бегонії Шмідта є розчин IOK (25 мг/л) i вода, при якому інтегрований показник укорінення становить $67 \%$.

17 травня ми висадили живці в універсальний грунт для подальших спостережень. Приживлюваність усіх досліджуваних бегоній - 100 \%. 3 усіх висаджених живців почали розвиватися молоді рослини, проте внаслідок недостатнього поливу згодом загинули листкові живці бегонії Шмідта.

Станом на 23 жовтня всі варіанти утворили рослини, які перебували на стадії підготовки до цвітіння або рясного цвітіння. Аналізуючи стан молодих рослин бегонії манжетної, відзначимо, що рослини добре розвивалися й утворили по 4-12 листків. У бегонії металевої в рослин розвинулося по 6-7 листків на стеблах довжиною 16-24 см. Молоді рослини бегонії тигрової досягли 1,5-5 см та утворили 5-8 листків. Молоді рослини бегонії Шмідта, висаджені стебловими живцями, почали гарно розвиватися. Довжина їхніх пагонів сягнула 18-43 см, у деяких рослин спостерігали рясне цвітіння.

\section{Висновки}

Для вегетативного розмноження бегоній коралової, люцерна, металевої й Шмідта ми рекомендуємо використовувати стеблові живці, які добре реагують на екзогенне внесення IMK (25 мг/л).

Стеблові живці, які містились у воді без дії фітогормонів, загинули в бегоній коралової та люцерни, задовільно вкоренились - у металевої й Шмідта. Живці досліджуваних варіантів потребують екзогенного впливу ауксинів.

Найкращим стимулятором ризогенезу для листкових живців бегоній манжетної й Шмідта $\epsilon$ розчин IOK (25 мг/л), при якому спостерігали добре вкорінення, для бегонії тигрової - розчин
IMK (25 мг/л), при якому вкорінення задовільне. Загалом на екзогенне внесення IOK (25 мг/л) листкові живці бегонії реагують специфічно. Через загибель усіх листкових живців бегоній люцерна та металевої вважаємо доцільним продовжити подальші їх дослідження.

Приживлюваність усіх досліджуваних видів бегоній - $100 \%$. Усі варіанти утворили рослини, які перебували на стадії бутонізації або рясного цвітіння.

\section{Література}

1. Алехина, Н. Д.; Балконин, Ю. В.; Гавриленко, В. Ф.; Ермакова, И. П., Ред.; Физиология растений: учебник; Академия: Москва, 2005, с 434-437.

2. Бугайчук, А. Ю.; Сеньків, І. В.; Андреєва, В. В. Вплив фітогормонів на вкорінення кімнатних рослин. Науковий вісник СНУ імені Лесі Українки; Луцьк, 2014, № 13 (290), с 30-35.

3. Копейка, В. И. Декоративные растения для дома, квартиры и офиса. Донецк; 2010, с 79-83.

4. Крупичева, И. Комнатное иветоводство. Растения в интерьере; Изд-во Эскимо: Москва, 2005, с 22-23.

5. Методичні рекомендації з розмноження деревних декоративних рослин ботанічного саду НУБіП Украӥни; Киев, 2008, с 17-22.

6. Поликарпова, Ф. Я.; Пилюгина, В. В. Выращчивание посадочного материала зеленым черенкованием; Росагропромиздат: Москва, 1991, с 51-61.

7. Попова, Н. Я.; Родина, Е. А. Опит применения стимуляторов роста в лесном хозяйстве. Лесоразведение и лесомелиорация; 1984, Вип. 1, с 2-5.

8. Приходько, С. Н. Михайловская М. В. Цветы в квартире; Киев, Урожай, 1992, с 32-36.

9. Сеньків, І. В.; Андреєва, В. В. Особливості укорінення листкових живців роду Begonia L. Сборник научных трудов SWord. 2015; Научный мир: Иваново, Вып. 3 (40), Т. 12, Биология. Медицина, ветеринария и фармацевтика. Химия. Физика и математика, с 4-7.

10. Тамберг, Т. Г.; Овчинников, Ю. А. Бегонї̈; Львів, 1989, с 46-52.

11. Хадсон, Хартманн; Дейл, Кестер. Размножение растений. практич. пособие для профессионалов и любителей; ЗАО Изд-во Центрполиграф: Москва, 2002, с 179-201.

12. Цицилин, А. Н. Фитодизайн: как вирастить здоровый воздух в офисе и дома; Эксмо: Москва, 2011, с 110-113.

13. Черевченко, Т. М.; Капустян, В. В.; Яременко, Л. М. Довідник квітникаря-любителя; Урожай: Киев, 1994, с 160-164.

14. Чувикова, А. А.; Потапов, С. П.; Черных, Т. Г.; Коваль, А. А. Практикум по цветоводству; Колос: Москва, 1984, с 115-117. 